\title{
MIĘDZY EKONOMIĄ A TEOLOGIĄ: EKONOMICZNE ARCHETYPY ZIEMI W PIĘCIOKSIĘGU
}

\section{O interdyscyplinarności i ekonomii ponad ekonomią}

„Interdyscyplinarność” stała się pojęciem dosyć modnym. I choć sporo wokół tego zagadnienia dyskusji, to, jak się wydaje, postulat interdyscyplinarności jest konieczny, by sprostać złożoności poszukiwań naukowych (które wszak są zwierciadłem złożoności świata) i budowaniu jedności wiedzy. Paradoksalnie, im większa specjalizacja w poszczególnych dyscyplinach, tym większa potrzeba interdyscyplinarności. Interdyscyplinarność znajduje swoich przeciwników i zwolenników, i dobrze. Zawsze jest to kwestią „namiętności poznawczych poszczególnych badaczy". ${ }^{1}$ Nietrudno zgadnąć, po której stronie stoi autorka tekstu. Uważam, że na styku obszarów przygranicznych zachodzą ciekawe zjawiska i zależności. Tym samym dołączam $^{2}$ do grupy heterodoksyjnych ekonomistów, którzy starają się badać pewne zjawiska, łącząc przy tym ujęcia różnych nauk. Choć owa chęć wychodzenia „ponad ekonomię” nie jest niczym nowym, o czym można przekonać się, śledząc historię myśli ekonomicznej, tendencja ta zyskuje jednak systematycznie na znaczeniu.

S. W r ó b e 1, Interdyscyplinarność jako efekt dyscyplinarności, w: J. K u r c z e w s k a, M. L e j z e r o w i c z (red.), Głosy w sprawie interdyscyplinarności, Warszawa 2014, s. 23-24.

2 Pierwszym moim tekstem wychodzącym z obszaru ,pogranicza” (ekonomii i katolickiej nauki społecznej) był rozdział Człowiek i ekonomia w świetle katolickiej nauki społecznej zawarty w: Ł. H a rd, D. M i lc z a r e k-A n d r z e j e w s k a (red.), Ekonomia jest piękna? Księga dedykowana Profesorowi Jerzemu Wilkinowi, Warszawa 2015, s. 27-44. 
Jako ekonomista rolny w sposób naturalny interesuję się zagadnieniami dotyczącymi ziemi. Ziemia jest $\mathrm{w}$ ekonomii jednym $\mathrm{z}$ podstawowych czynników produkcji, a więc jest to czynnik niezbędny, dlatego znaczenia ziemi nie sposób przecenić. Ziemia ma jednak nie tylko wartość ekonomiczną, ale również społeczną i kulturową. $\mathrm{O}$ ziemi zatem może mówić nie tylko ekonomista. Z drugiej strony, mając mandat interdyscyplinarności, ekonomista może analizować kategorię ziemi, zresztą na wskroś ekonomiczną, nie tylko w obrębie swojej dyscypliny, i może poszukiwać wątków ekonomicznych w obszarach na pierwszy rzut oka, wydawałoby się, mało związanych z ekonomią. Takim „obszarem” jest Pismo Święte, a szerzej, teologia. Uważam, że Biblia jest doskonałym, a nieodkrytym do końca, źródłem wielu inspiracji ekonomicznych.

Źródła kształtowania współczesnych systemów ekonomicznych biją właśnie w religii. Max Weber - ekonomista i socjolog, historyk i religioznawca, dowodził, że „duch kapitalizmu” pochodzi z etyki protestanckiej. ${ }^{3}$ Współczesny Weberowi, zresztą jego przyjaciel, Werner Sombart polemizował z tym stwierdzeniem, uważając, że za powstanie kapitalizmu odpowiada wiara żydowska i to Żydom świat zawdzięcza „wynalezienie” kapitalizmu. ${ }^{4}$ Zostawiając spór nierozstrzygnięty, uznając, że ,duch kapitalizmu” flat ubi vult, ${ }^{5} \mathrm{w}$ poszukiwaniu źródeł nowożytnej myśli ekonomicznej dotyczącej ziemi, sięgnęłam do pierwszej części Biblii chrześcijańskiej, do Starego Testamentu. Naturalnym wyborem stał się Pięcioksiąg, jako zbiór

3 Por. M. W e b e r, Etyka protestancka i duch kapitalizmu, tłum. D. L a c h ow s k a, Warszawa 2015.

4 Por. W. S o m b a r t, Żydzi i życie gospodarcze, tłum. M. B r o k m a n o w a, Warszawa 2010 (reprint z 1913 r.). Sombart gloryfikuje geniusz ducha żydowskiego i stwierdza dobitnie: „Religię żydowską i kapitalizm charakteryzują te same idee zasadnicze, są one tym samym duchem przesiąknięte" (s. 201), ujmując to poetycko: „Jako słońce wędruje Izrael przez Europę: za jego przyjściem budzi się nowe Życie, a z jego odejściem więdnie to, co dotychczas kwitnęło" (s. 13).

5 Parafraza zaczerpnięta została z recenzji książki W. Sombarta, Żydzi i życie gospodarcze; zob. I. B u k r a b a - R y l s k a, „Duch kapitalizmu”, czyli spiritus fiat ubi vult, Wieś i Rolnictwo 151(2011) nr 2, s. 164-167. 
pism uznanych za pouczające słowo Boga (Tora) i przedstawiających początkowy etap historii ludzkości i narodu wybranego.

\section{Wartość ziemi}

Ekonomista rolny Ryszard Manteuffel w napisanej u schyłku swego życia Filozofii rolnictwa stwierdził: „Człowiek jest (...) produktem ziemi. (...) Ziemia jest naszym bliskim krewnym, składamy się bowiem z tych samych pierwiastków. ${ }^{6}$ (...) Ja odczuwam bardzo silnie to pokrewieństwo z ziemią. (...) Nieraz gdy chodzę po pulchnej, pięknie uprawionej orce, chciałbym - gdyby to wypadało mnie staremu - wytarzać się w niej, by mieć kontakt osobisty z ziemią, moją rodzicielką". ${ }^{7}$ Ta intuicja poczucia fizycznej jedności z ziemią doskonale komponuje się z opisem stworzenia świata, przedstawionym w Księdze Rodzaju. Oto bowiem „Pan Bóg ulepił człowieka z prochu $\mathrm{ziemi}^{8}{ }^{8}$ a następnie tchnął w jego nozdrza tchnienie życia" (Rdz 2, 4-7). Ziemia w ten sposób nabrała dodatkowego znaczenia, stała się nie tylko doczesnym domem człowieka, stworzonym przez Boga ,na początku" (por. Rdz 1, 1), ale także materialnym budulcem ludzkiego ciała. Jako ludzie, choć nosimy w sobie pierwiastek nieśmiertelności, jesteśmy także częścią tego świata, tej ziemi.

Jak podaje Pismo Święte, Bóg na ziemi stworzył człowiekowi idealne warunki do rozwoju, czyniąc ziemię urodzajną, dającą życie

6 Ciało ludzkie składa się z tym samych pierwiastków, które zawarte są w glebie, tylko w innych proporcjach ilościowych (tlen, węgiel, wodór, azot, wapń, fosfor, potas, siarka, chlor, sód, magnez, żelazo, mangan, miedź, jod), por. R. M a n t e u f f e 1, Filozofia rolnictwa, Warszawa 1987, s. 44-46.

7 Tamże, s. 44.

8 Choć możemy przyjąć dosłownie wyraz ,proch ziemi” użyty przez autora natchnionego, z którego Bóg stworzył ciało człowieka, można również go uznać za pewnego rodzaju metaforę, mającą służyć jedynie podkreśleniu tego, że człowiek składa się z elementu przemijającego, materialnego, wcale nie usiłując bliżej podkreślać natury tego elementu; por. S. Ł a c h, Księga Rodzaju. Wstęp, przekład z oryginału, komentarz, w: t e n ż e (red.), Pismo Święte Starego Testamentu, Poznań 1962, t. 1, cz. 1, s. 200. 
matkę karmicielkę. Tę piękną ziemię Bóg powierzył człowiekowi we władanie, by czynił ją sobie poddaną (por. Rdz 1, 28), a więc, by ją uprawiał, doglądał i pielęgnował (por. Rdz 2, 15) i podtrzymywał swoje życie, żywiąc się pokarmem, który wyda ziemia (por. Rdz 1, 29). Z Bożej mądrości człowiekowi została dana misja uprawy ziemi, powiedzieć można, kształtowania kultury rolniczej. I człowiek podjął tę misję, i niesie ją do dnia dzisiejszego, gdyż musi produkować potrzebny mu do życia pokarm.

Ziemia stała się jednak areną dramatu ludzkiej egzystencji, z powodu, jak tłumaczy Pismo Święte, grzechu pierworodnego. Bóg wypowiedział słowa: „Przeklęta niech będzie ziemia (...): w trudzie będziesz zdobywał od niej pożywienie dla siebie po wszystkie dni twego życia. Cierń i oset będzie ci ona rodziła, a przecież pokarmem twym są płody roli” (Rdz 3, 17-19). I tak jest do dziś: z jednej strony ziemia jest wciąż ziemią żyzną, która daje człowiekowi pokarm i podtrzymuje jego życie, a z drugiej strony niełatwo rodzi owoce, wymaga uprawiania, wysiłku, a jej plony nie są pewne.

Szczególne miejsce ziemi w produkcji potwierdza ekonomia. W każdym podręczniku ekonomii znajdujemy informację, że jest ona jednym z trzech klasycznych czynników produkcji (obok pracy i kapitału). W produkcji rolniczej ujawnia się wyjątkowa rola ziemi, ${ }^{9}$ która jest tu nie tylko miejscem produkcji, ale także jako środek produkcji stanowi „zaczyn” naturalnych procesów produkcji roślinnej. Jakość ziemi wyraża się w jej naturalnej sile produkcyjnej wytworzonej nie przez człowieka (sic!) (chociaż adaptacja ziemi dziewiczej do produkcji rolniczej wymaga wysiłku człowieka - czy nie przypomina to biblijnego „,czynienia sobie ziemi poddaną” oraz zdobywania dla siebie pożywienia w trudzie?).

9 O znaczeniu ziemi w ekonomii rolnej pisali m. in. A. W o ś, F. To m c z a k, Ekonomika rolnictwa. Zarys teorii, Warszawa 1979; A. W o ś, Ekonomika odnawialnych zasobów naturalnych, Warszawa 1993. 
Jeżeli ziemię ${ }^{10}$ uprawia się w sposób racjonalny, można nie tylko zachować jej naturalne walory, ale nawet ją wzbogacić. Pod tym względem ziemia różni się od innych środków produkcji, które są wytworem pracy ludzkiej i które zużywają się w procesie produkcji. Ten pierwotny i niezniszczalny walor ziemi świadczy o jej naturalnych właściwościach: o jej zasobności w naturalne składniki i możliwości uprawy. Czy nie przywodzi to na myśl podtrzymywanej do dziś żyzności ziemi nadanej mocą stwórczą Boga?

Naukowcy są zgodni, że pierwotna żywotność, żyzność ziemi, nie jest spowodowana przez człowieka. Niektórzy nazywają to „darem natury”, „darem przyrody”, inni wprost przyznają, że ziemia jest darem Boga. Znamienne, że dwaj współcześni polscy ekonomiści rolni, podczas wykładów wygłoszonych na uroczystości nadania im doktoratów honoris causa, sięgają do źródeł Pisma Świętego, uznając Boga za Stwórcę ziemi. Profesor Andrzej Czyżewski głosił tak: ,Ziemia zaliczana do majątku, nie jest przecież zgromadzonym przez człowieka kapitałem. Posiada wartość samoistną, która przez stulecia użytkowania była ulepszana (...), ale jej korzenie leżą przecież w nadaniu Stwórcy". ${ }^{11}$ Profesor Jerzy Wilkin zaś powiedział tak: „Jesteśmy interesariuszami ziemi rolniczej, tego wspaniałego zasobu - Bożego daru". ${ }^{12}$

Oczywistością będzie stwierdzenie, że ziemia, jej istnienie, jest warunkiem naszej egzystencji, zatem należy się jej szacunek

10 Ściślej mówiąc, w ekonomii rolnej rozróżnia się pojęcie gleby, jako wierzchniej warstwy skorupy ziemskiej, której cechy fizyczne, chemiczne i biologiczne czynią ją przydatną dla celów rolniczych. Gleba jest zasobem przystosowanym do użytkowania rolniczego. Jest zasobem odnawialnym, który przez odpowiednią uprawę można odtwarzać, ale nie może zwiększać ilości ziemi, z którą ta gleba jest związana; por. tamże, s. 244-246. Na potrzeby tego tekstu będę jednak używać pojęcia „ziemia”.

11 A. C z y ż e w s k i, Odkrywanie ekonomii rolnej, Agricola 94/2016, s. 16 (wykład z okazji nadania godności doktora honoris causa Szkoły Głównej Gospodarstwa Wiejskiego w Warszawie, 26 XI 2015 r.).

12 J. W i 1 k i n, Ziemia rolnicza - wielki skarb naszej planety, tamże, s. 21. (wykład z okazji nadania godności doktora honoris causa Szkoły Głównej Gospodarstwa Wiejskiego w Warszawie, 26 XI 2015 r.). 
i opieka. I gdyby nawet nie z tego powodu, że jest ona darem Bożym, to ze względu na to, że bez ziemi, rolnictwa i uprawy roli, człowiek nie mógłby istnieć. Istnienie ziemi implikuje istnienie człowieka. Jak wyraża to ekonomia, zasób ziemi spełnia funkcję użyteczności. Ta funkcja jest niezastępowalna. Unikatowa rola ziemi i rolnictwa jest niepodważalna, choć znaczenie (ale nie rola) rolnictwa w skali światowej się zmniejsza. ${ }^{13}$

Utrzymywanie odpowiednich zasobów ziemi rolniczej jest niezbędne do zapewnienia bezpieczeństwa żywnościowego (food safety); chodzi o zapewnienie stopnia samowystarczalności żywnościowej w skali każdego kraju, jak też w skali światowej. Z drugiej strony, palącym problemem w obliczu nadmiernej ingerencji człowieka w proces produkcji stało się otrzymywanie bezpiecznej, a więc zdrowej żywności (food security). Jednocześnie, zwłaszcza w Europie, obserwuje się zjawisko porzucania ziemi rolniczej, wyłączanie jej z użytkowania rolniczego (land abandonment). ${ }^{14}$ „A paradoksem jest fakt, że ziemia rolnicza w pewnych warunkach traktowana jest współcześnie jako «brązowe złoto», a w innych jako «balast» skazany na porzucenie”. ${ }^{15}$ To jeden z kontrowersyjnych obrazów „czynienia sobie ziemi poddaną" przez współczesnego człowieka.

Tym bardziej że ziemi, matce żywicielce, na przestrzeni dziejów nadawano wartość niemal sakralną. Poczuwano się głęboko do

13 Prawidłowość jest taka, że wraz z rozwojem gospodarczym kraju kurczy się sektor rolnictwa, na rzecz sektora usług. W najbardziej rozwiniętych krajach świata w rolnictwie zatrudnionych jest zaledwie kilka procent, podobna sytuacja występuje w przypadku udziału rolnictwa w tworzeniu dochodu narodowego. Np. w Niemczech odsetek pracujących w rolnictwie wynosi 1,3\%, we Francji-2,8\%; za I. F r e n k e 1, Ludność rolnicza, w: te n ż e, Polska wieś 2016. Raport o stanie wsi, Warszawa 2016 (w druku). W Polsce odsetek ten kształtuje się (2014 r.) na poziomie 15,5\%, przy udziale rolnictwa w PKB 2,9\%; por. Rocznik Statystyczny Rolnictwa, GUS, Warszawa 2015, s. 37.

${ }_{14}$ Por. D. M i lczarek-A nd r zejew s ka, K. Z aw a lińs ka, Konflikty wokót ziemi - czy Wspólna Polityka Rolna może je łagodzić? w: Ł. H a r d, D. M i l c z a r e k - A n d r ze je w s k a (red.), Ekonomia jest piękna? Księga dedykowana Profesorowi Jerzemu Wilkinowi, s. 408.

15 Tamże. 
obowiązku jej uprawy. We wspomnieniach Zofii Kossak-Szczuckiej z wysiedlania ziemian kresowych znajdujemy opis głębokiego, można rzec, zakorzenionego, poczucia obowiązku obsiania ziemi. ${ }^{16}$ Autorka wspomina, że w czasie opuszczania majątków, domów i ziem, nie tylko zasiano oziminy, ale pozostawiono zasiew wiosenny w spichlerzach, choć można było sprzedać to ziarno przed ucieczką z ojcowizny. Jednak zwyciężała miłość do ziemi i poczucie obowiązku obsiania ziemi, niezależnie komu plon przypadnie. ${ }^{17}$

Ziemia spełnia bowiem funkcje nie tylko ekonomiczne. Ziemia ma wartość społeczną. I chociaż ekonomiści tzw. głównego nurtu skłonni są analizować zasoby ziemi w kontekście jednej wartości: rynkowo-pieniężnej, której wyrazem jest produktywność i efektywność ekonomiczna, są i tacy, którzy zauważają inne jej wymiary, mówiąc o ,wielofunkcyjności rolnictwa” i ,wielofunkcyjności ziemi”. ${ }^{18}$ Ziemia rolnicza nie powinna być uważana jedynie za czysty „,czynnik produkcji” czy „zasób produkcyjny”. Z ziemią rolniczą wiąże się wiele funkcji czy znaczeń kulturowych, społecznych, sentymentalnych, nawet politycznych.

Badania autorki tekstu nad wielozawodowością rodzin rolniczych pokazały, że jako motyw kontynuowania (niedochodowej) działalności rolniczej, ok. 1/3 wskazań respondentów dotyczyła odpowiedzi,

16 Por. Z. K o s s a k - S z c z u c k a, Pożoga, Warszawa 2015, s. 61.

17 Pięknie opisuje to, w literackiej formie, P. Zuchniewicz w opowieści z czasów wojny, o kard. Stefanie Wyszyńskim. „Pochwalony Jezus Chrystus! - Na wieki wieków! - Panie gospodarzu, nadziwić się nie mogę. Wszyscy uciekają, wszyscy się boją, a pan sieje? - Ksiądz też się boi? - zapytał rolnik. - Pewnie, że tak. Nie inaczej ja. Ale powiem księdzu, że jakbym to zboże zostawił w spichrzu, to spłonie. A jak wrzucę w ziemię, to zawsze ktoś z tego chleb będzie jadł. - Nawet wróg? - Chleb je człowiek"; P. Z u c h n i e w i c z, Ojciec wolnych ludzi. Opowieść o Prymasie Wyszyńskim, Kraków 2011, s. 27.

18 Wśród nich wyróżnia się J. W i 1 k i n, Wielofunkcyjność rolnictwa. Kierunki badań, podstawy metodologiczne i implikacje praktyczne, w: t e n ż e (red.), Warszawa 2010; t e n ż e, Ziemia rolnicza - dobro wielofunkcyjne, Wieś i Rolnictwo 162(2014) nr 1, s. 113-121, A. W o ś, J. Z e g a r, Rolnictwo społecznie zrównoważone, Warszawa 2002. 
iż ziemia ma wartość sentymentalną. ${ }^{19}$ Ową ,,sentymentalność” znajdujemy w Piśmie Świętym. Gdy naród Izraela mieszkał w Egipcie, w kraju Goszen, Jakub na łożu śmierci prosił Józefa, by nie pogrzebał go w Egipcie, ale w grobie przodków, przy jego praojcach, w pobliżu Mamre w kraju Kanaan (por. Rdz 49, 29-31). Tak samo Józef, przed śmiercią zapowiadając braciom wyprowadzenie ich z ziemi egipskiej do kraju, który Bóg obiecał Abrahamowi, Izaakowi i Jakubowi, zobowiązał braci przysięgą: „Gdy Bóg okaże wam tę wielką swoją łaskawość, zabierzcie stąd moje kości” (Rdz 50, 25). Wartość ziemi ojczystej odnajduje zatem każde pokolenie, od biblijnego ludu do dzisiejszych pokoleń. Wiele krajów doświadczyło, ile tak naprawdę znaczy ziemia, w sytuacjach perturbacji politycznych, związanych ze zmianami granic czy zmianą statusu państwowości.

Dla narodu wybranego ojczyzną była Ziemia Obiecana, do której Bóg wezwał Abrama, objawiając się mu w Charanie, po jego przybyciu do tego miasta z Ur: „Wyjdź z twojej ziemi rodzinnej i z domu twego ojca do kraju, który ci ukażę. Uczynię bowiem z ciebie wielki naród" (Rdz 12, 1). Bóg zażądał od Abrama oderwania się od naturalnych przywiązań przez opuszczenie ziemi rodzinnej. Mimo że niełatwo było spełnić rozkaz powołania Bożego, opuścić wszystko $i$ iść do ziemi nieznanej, Abram uczynił to, umacniany obietnicą wielkiej nagrody: błogosławieństwa Bożego. Gdy doszedł do ziemi Kanaan, w specjalnym widzeniu w Sychem, Bóg przyrzekł Abramowi po raz pierwszy, że potomstwu jego odda na własność ziemię Kanaan (por. Rdz 12, 7).

Biblijny Kanaan stał się ziemią rodzinną, ojcowizną narodu wybranego. ${ }^{20}$ Kiedy Jakub, syn Izaaka, po skradzeniu pierworództwa

19 Por. M. B łą d, Wielozawodowość w rodzinach rolniczych. Przyczyny, uwarunkowania i tendencje rozwoju, Warszawa 2011, s. 189.

20 Współcześni Żydzi powołują się na argument biblijny przedstawiający Palestynę jako Ziemię Obiecaną i daną przez Boga ich przodkom, jako uprawomocnienie, względem ludności arabskiej osiadłej tam od ponad półtora tysiąca lat, ich praw zamieszkania na tej ziemi. Ziemia Izraela i państwo Izrael obok judaizmu stały się zwornikami narodowej tożsamości żydowskiej, zwłaszcza po utworzeniu w $1948 \mathrm{r}$. w Palestynie państwa Izrael dla Żydów pozbawionych przez prawie dwa tysiące 
swemu bratu, Ezawowi, przebywał w Charanie, pasąc trzody Labana, był na obczyźnie. Jemu, po 20 latach służby, powiedział Pan: „Wróć do ziemi twych przodków, do twego kraju rodzinnego, Ja zaś będę z tobą" (Rdz 31, 3). Nawet wtedy, gdy potomstwo Abrahama przebywało przez ponad 400 lat w Egipcie, żyło jako „obcy” w kraju, który nie należał do niego (por. Rdz 15, 13). Jednak, jak wiemy z historii biblijnej, Bóg, zważając na swe przymierze i obietnicę daną Abrahamowi, postanowił wywieźć naród wybrany z niewoli i zaprowadzić na powrót do ziemi Kanaan, „do ziemi żyznej i przestronnej” (Wj 3, 8), do ich ojczyzny wybranej i nadanej im przez Boga. ${ }^{21}$

Krainę Kanaan sam Bóg nazwał ziemią opływającą w mleko i miód ${ }^{22}$ (por. Wj 3, 17). Ta fraza weszła do obiegu powszechnego jako oznaczenie żyznej ziemi, miejsca, w którym wszystkiego jest pod dostatkiem, a więc bogatego kraju. Bóg dał zatem ludowi swemu to, co najlepsze. Ale, jak widzimy we współczesnym świecie, kiedy człowiek nie przestrzega praw ziemi, łamiąc pierwotną harmonię między sobą a ziemią,

lat własnego terytorium i państwowości; por. W. C h r o s t o w s k i, Czyja Ziemia Święta-panorama historyczna, Collectanea Theologica 74(2004)2, s. 9-10.

${ }_{21}$ Jak podaje W. Chrostowski (za S. Pecaric): „Gdyby narody świata powiedziały Izraelowi: «Jesteście złodziejami, bo podbiliście ziemię siedmiu narodów, które zamieszkiwały ziemię Kanaan», wtedy Izrael im powie: «Cały Świat należy do Świętego Jedynego (Niech będzie błogosławiony!). On go stworzył i podarował, komu uznał za stosowne. Jego wolą było dać im i tę ziemię i Jego wolą było ją im odebrać, a przekazać nam»”; t e n ż e, „Historia początków” (Rdz 1-11) w interpretacji żydowskiej, Collectanea Theologica 83(2013)4, s. 120.

22 Jak pokazuje historia początków kultury agrarnej, poświadczona przez archeologów, właśnie na Bliskim Wschodzie na obszarze tzw. Żyznego Półksiężyca (który obejmuje biblijną krainę Kanaan) rozpoczęła się neolityczna rewolucja agrarna, a więc przejście od gospodarki zbieracko-myśliwskiej do gospodarki wytwarzającej (rolniczo-hodowlanej). Było to możliwe głównie dzięki zaletom środowiska Żyznego Półksiężyca: warunkom klimatycznym strefy śródziemnomorskiej (łagodne, wilgotne zimy oraz długie, gorące i suche lata), obfitości dzikich przodków roślin uprawnych i ich wysokiej produktywności (bogactwo zasobów naturalnych) związana ze zróżnicowaniem topograficznym (różnicami wysokości) oraz dużym udziałem gatunków obupłciowych, czyli samopylnych we florze Bliskiego Wschodu; por. J. D i a m o n d, Strzelby, zarazki, maszyny Losy ludzkich społeczeństw, tłum. M. K o n a r z e w s k i, Warszawa 2000, s. 109-112. 
zatraca sacrum ziemi, to wtedy ziemia sprzeniewierza się człowiekowi; i jak echo wracają słowa Boga: „Przeklęta niech będzie ziemia z twego powodu (...) cierń i oset ci będzie rodziła" (por. Rdz 3, 17-19).

\section{Własność ziemi, konflikty o ziemię}

Ziemia jest nierozłącznie związana $\mathrm{z}$ własnością i kwestią praw własności. „Jednym z fundamentalnych zasad gospodarki rynkowej jest ustanowienie $\mathrm{w}$ systemie prawnym dobrze zdefiniowanych praw własności. Bez odpowiednich uprawnień do własności gruntów i nieruchomości na nich położonych, spory prawne będą hamować efektywność gospodarki". ${ }^{23}$ Tak głosi logika współczesnej ekonomii. A co na ten temat mówi Pismo Święte? Otóż, skoro ziemię stworzył Bóg, do Stwórcy należy Jego dzieło. Bóg jednak w swym zamyśle miłości do człowieka, w rezultacie zawartego przymierza, dał narodowi wybranemu ziemię w posiadanie. Księga Powtórzonego Prawa głosi: „Lecz gdy przejdziecie Jordan i osiądziecie w ziemi, którą Pan Bóg wasz daje wam na własność, a On udzieli wam pokoju ze strony wszystkich wrogów okolicznych - żyć będziecie bezpiecznie" (Pwt 12, 10).

Ziemia Obiecana była zatem ważna nie tylko dlatego, że była ziemią żyzną, ale głównie dlatego, że była darem Boga, że Bóg właśnie ją przeznaczył dla swych wybranych, Abrahama i jego potomków. Kraj ten stał się ich własnością nadaną mocą Boga. Gwoli ścisłości, „Izraelici będą i jednocześnie nie będą właścicielami Kanaanu. Będą, ponieważ otrzymali go w nadaniu od Boga. Nie będą, ponieważ ten kraj należy do Boga”. ${ }^{24}$ Innymi słowy, „Bóg posiada ziemię, a człowiek jest jej użytkownikiem”. ${ }^{25}$ Dlatego zastrzegł Pan: „Nie wolno sprzedawać ziemi na zawsze, bo ziemia należy do Mnie, a wy jesteście u Mnie przybyszami i osadnikami” (Kpł 25, 23).

${ }_{23}$ M. S k o u s e n, Logika ekonomii, tłum. B. P a w iń s k i, Warszawa 2015, s. $225-226$.

24 G. W it a s z e k, Biblijne podstawy własności prywatnej, w: t e n ż e (red.), Życie społeczne w Biblii, Lublin 1997, s. 26.

25 Tamże. 
Z chwilą przybycia do Kanaanu, każdy członek tego narodu (z wyłączeniem lewitów), drogą losowania, otrzymał równy dział ziemi, który miał mu zagwarantować środki do utrzymania (por. Lb 26, 52-56). W ten sposób Bóg w swej mądrości zapewnił każdemu ekonomiczną samowystarczalność. Wylosowany dział miał pozostać $\mathrm{w}$ wiecznym posiadaniu danej rodziny. Własność rodzinna była uznana zatem za najlepszą formę własności. Niewiele zmieniło się przez wieki; również i współcześnie uznawana jest ona za optymalną formę gospodarowania ziemią. Gospodarstwa rodzinne, ta „odwieczna forma działalności rolniczej”, ${ }^{26}$ stanowią nadal powszechną formę rolnictwa w dzisiejszym świecie. Istnieją one także w krajach wysokorozwiniętych, mimo ekspansji przedsiębiorstw rolnych. ${ }^{27}$

W celu ochrony biblijnej własności rodzinnej ustanowiono prawo spadkowe, zabraniające przekazywania spadku w obce ręce. Ziemia w spadku nie była dzielona jak inne dobra, lecz przechodziła na pierworodnego lub pozostawała niepodzielna. ${ }^{28}$ Szczegółowe warunki dziedziczenia znajdujemy m. in. w Księdze Liczb 27, 8-11 i Księdze Powtórzonego Prawa 21, 15-17. W zachowaniu rodzinnej ziemi niepodzielonej kryje się mądrość, bowiem i we współczesnej ekonomii uznaje się, że struktura obszarowa gospodarstw rolnych ma decydujące znaczenie dla efektywnego wykorzystania pozostałych czynników produkcji, czyli pracy i kapitału. ${ }^{29}$ Rozdrobnienie agrarne

26 Por. J. Z e g a r, Gospodarstwa rodzinne wobec wyzwań wyżywienia i ochrony środowiska-ujęcie globalne, Wieś i Rolnictwo 125(2012)4, s. 54.

27 Jak napisał J. Zegar, „głównych zalet gospodarstw rodzinnych trzeba upatrywać nie tyle po stronie produkcji rolniczej, co w pełnieniu rozlicznych funkcji społecznych i środowiskowych o charakterze dóbr publicznych”, jak też „Gospodarstwo rodzinne to nie tylko fabryka żywności, ale także dom, rodzina, ważny element krajobrazu, ostoja regionalnych oraz narodowych tradycji i wartości”; tamże, s. 53,57. Konstatacje te świadczą o tym, że wartości gospodarstw rodzinnych nie można analizować jedynie w kontekście produktywność i efektywności ekonomicznej.

28 Por. G. W it a s z e k, Biblijne podstawy własności prywatnej, s. 28.

${ }_{29}$ Por. np. A. B a e r - N a w r o ck a, W. P o c z t a, Przemiany $w$ rolnictwie, w: J. W il k i n, I. N u r z y ń s k a (red.), Polska wieś 2014. Raport o stanie wsi, Warszawa 2014, s. 96-98. 
i ,szachownica gruntów” powoduje, że rolnictwo jest niskoprodukcyjne i mało ekonomiczne.

Parafrazując wyżej wymieniony passus z podręcznika ekonomii, można powiedzieć, że Bóg, jako najwyższy prawodawca, ustanowił w systemie prawnym Izraelitów dobrze zdefiniowane prawa własności, tworząc im ramy życia gospodarczego. Ważne przepisy regulujące własność gruntową i obrót ziemią znajdujemy również w postanowieniach dotyczących tzw. roku jubileuszowego, a więc uroczystego obchodzenia pięćdziesiątego roku, następującego po siedmiu okresach lat szabatowych. Łączył się on z nieuprawianiem ziemi i powrotem posiadłości ziemskich, bez żadnej zapłaty, do pierwotnych właścicieli. „Będzie to dla was jubileusz - każdy z was powróci do swej własności i każdy powróci do swego rodu" (Kpł 25, 10). Egzegeza biblijna wyjaśnia: „«Powrót do swojej własności» oznacza uwolnienie i przywrócenie z obcych rąk posiadłości gruntowej. Każdy otrzymywał to, co przedtem posiadał, a co utracił przez sprzedaż za długi, i każdy mógł teraz powrócić do swojej ojcowizny". ${ }^{30}$ Przepisy zezwalały na sprzedaż ziemi, jednak cena gruntu miała się kształtować odpowiednio niżej lub wyżej, w zależności od mniejszej czy większej odległości roku jubileuszowego (por. Pwt 25, 131-17). Transakcje musiały uwzględniać liczbę lat, w których ziemia będzie przynosiła plony nowemu właścicielowi. Odległość czasowa następnego roku jubileuszowego wyznaczała cenę sprzedaży, która, zgodnie z logiką ekonomiczną, była tym wyższa, im więcej lat było do jubileuszu. Słusznie zwrócił uwagę Gabriel Witaszek, że skoro w transakcji brano pod uwagę liczbę lat, dlatego de facto kupowano nie tyle grunt, ile pewną ilość zbiorów. ${ }^{31}$ Warto dodać, że prawo roku jubileuszowego wzywało do prawości w postępowaniu: „Kiedy więc będziecie sprzedawać coś bliźniemu albo kupować coś od bliźniego, nie wyrządzajcie krzywdy jeden drugiemu” (Kpł 25, 13).

30 S. Ła c h, Księga Kapłańska. Wstęp, przekład z oryginału, komentarz, ekskursy, t. 2, cz. 1, w: t e n ż e (red.), Pismo Święte Starego Testamentu, Warszawa 1970, s. 272.

31 G. W it a s z e k, Biblijne podstawy własności prywatnej, s. 37. 
Wnioskować można, że sprzedaż ziemi u Izraelitów nie odbywała się raz na zawsze (ziemia należy do Boga, a więc nie mogła być poddana sprzedaży ,absolutnej”), ale była formą dzisiejszej dzierżawy, z prawem do użytkowania ziemi i zbierania jej owoców; nabywający kupował ją bowiem na okres, który pozostał do roku jubileuszowego, a potem musiał ją oddać. Biblijne prawo dotyczące ziemi podkreślało zatem niezbywalny charakter własności rodzinnej. W tym duchu prawodawca uregulował także wykup własności gruntowej (Kpł 25, 24-28). Jeżeli Izraelita znajdzie się w ciężkim położeniu i będzie zmuszony do sprzedaży ziemi, to jego najbliższy krewny powinien nabyć ją od niego. Celem tego prawa było utrzymanie w obrębie krewnych dziedzictwa, którego głowa rodziny nie mogła zachować dla siebie. ${ }^{32}$

Prawo powyższe miało obowiązywać naród wybrany w krainie Kanaan. Wcześniej jednak, w dziejach Izraela odnajdujemy pierwszy opis transakcji (sprzedaży) ziemi, wraz z nabyciem do niej praw własności, dokonanej przez Abrahama, który w Hebronie, w ziemi Kanaan, chciał pochować swoją zmarłą żonę, Sarę (por. Rdz 23, 1-20). Choć był to kontrakt ustny, miał charakter zobowiązującego aktu prawnego. Abraham zwrócił się do Hetytów: „Choć mieszkam wśród was jako przybysz, sprzedajcie mi tu u was grób na własność" ( $\operatorname{Rdz} 23,3)$. Abraham potrzebował od nich zgody, by prowadzić z nimi interesy na równych prawach. Ponieważ Hetyci uznawali Abrahama za „człowieka szczególnie zaszczyconego przez Boga” ( $\operatorname{Rdz} 23,6)$, chcieli mu to pole podarować. Jednak Abraham nalegał, by zakupić ziemię. W efekcie transakcja sprzedaży została dokonana, za sumę wypowiedzianą przez Efrona. Jak podaje Katolicki komentarz biblijny, Abraham nie targował się z Efronem, być może dlatego, by zakup nie budził żadnych wątpliwości oraz w poczuciu godności własnej i Sary wobec tłumu cudzoziemców. ${ }^{33}$ Czytamy dalej w Biblii: „Odtąd pole i znajdująca się na nim pieczara przeszły

32 Tamże, s. 29.

33 Por. R. E. Brown, J. A. Fitzmyer, R. E. Murphy (red. wydania oryginalnego); W. Ch rost ow s k i (red. nauk. wyd. pol.), Katolicki komentarz biblijny, Prymasowska Seria Biblijna 17, Warszawa 2010, s. 42. 
od Chetytów i Abrahama jako tytuł własności grobu" (Rdz 23, 20). Fragment ten świadczy o mądrości Abrahama, który chciał mieć zapewnione prawne uregulowanie tytułu własności do ziemi. Ziemia kupiona od nich jako miejsce na chowanie swoich zmarłych była, jak wspomniano, pierwszą i jedyną własnością Izraelitów, aż do czasów Jozuego, który zdobył ziemię Kanaan.

Prawnego uregulowania chroniącego dostatecznie ziemię, będącą własnością nie tylko indywidualną, ale także własnością danego kraju (tak jak to było szczegółowo uregulowane u Izraelitów), potrzeba było tak kiedyś, jak i dziś. Ziemia bowiem może być (i bywa) konfliktogenna, z powodu jej ograniczoności, skończoności, a przy tym niezbędności. Teorie ekonomiczne upatrują źródło problemów ekonomicznych właśnie we względnym niedoborze, ograniczoności zasobów (w tym zasobów ziemi) wobec nieograniczoności wzrastających potrzeb człowieka. W Piśmie Świętym spotykamy się z przykładem ograniczoności zasobów ziemi i sposobu jej rozwiązania. Oto kiedy Abram wywędro$w{ }^{34} \mathrm{z}$ Egiptu wraz ze swoją żoną i dobytkiem oraz z Lotem, i dotarli do Betel, okazało się, że „kraj nie mógł utrzymać ich obu, bo zbyt liczne mieli trzody" (Rdz 13, 6). Autor biblijny wskazuje na ograniczoność ziemi i brak paszy dla licznych trzód jako przyczynę kłótni pasterzy.

Współczesna ekonomia mówi nam o tzw. tragedii wspólnego pastwiska. Chodzi o to, że w sytuacji własności publicznej występuje tendencja do zbyt intensywnego używania zasobów. Gdy nie ma uregulowanej własności ziemi (tu: pastwiska), każdy pasterz ma interes w dodaniu kolejnego zwierzęcia do swojego stada korzystającego z tego pastwiska, co prowadzi do zbyt intensywnego wypasania zwierząt, w efekcie „wolność wykorzystania publicznego zasobu

34 Dodać można, że styl życia Abrahama, jak i innych patriarchów izraelskich, był „pół nomadyczny”; ludność ta nie najeżdżała zbrojnie osiadłej ludności, lecz pokojowo nawiedzała okolice przez nią zamieszkane, szczególnie w lecie, po żniwach. Na mocy dobrowolnej umowy z rolniczą ludnością wypasała swoje trzody na uprzątniętych ze zboża polach. Ich zaś czasowe wędrówki były powodowane prawem tzw. zmiany pastwisk między stepem a ziemią uprawną; por. S. Ł a c h, Księga Rodzaju. Wstęp, przekład z oryginału, komentarz, s. 335. 
prowadzi do ruiny wszystkich". ${ }^{35}$ Tak oto brak praw własności może tworzyć „tragedię wspólnego pastwiska”.

Wróćmy do Księgi Rodzaju. Gdy wynikła sprzeczka między pasterzami trzód Abrama i Lota, Abram zaproponował Lotowi, by rozwiązać spór i rozłączyć się: „Odłącz się ode mnie! Jeżeli pójdziesz w lewo, ja pójdę w prawo, a jeśli ty pójdziesz w prawo, ja w lewo" (Rdz 13, 9). Objawiła się tu mądrość Abrama, który nie chciał przedłużać kłótni między bliskim krewnymi, ze względu na otaczającą ich ludność niesemicką, jaką stanowili Kananejczycy. Nie bacząc na swe starszeństwo i otrzymane obietnice, Abram dał Lotowi prawo wyboru okolicy. Lot wybrał urodzajną ziemię wokół doliny Jordanu (leżącą w okolicach Sodomy) i odłączył się od Abrama, który pozostał w Kanaanie. ${ }^{36}$ Było to pokojowe rozstanie i polubowne rozwiązanie „konfliktu” o ziemię.

Nie zawsze jednak konflikty o ziemię, będące de facto walką o władzę, rozwiązywane są pokojowo, czego przykład widzimy już w Księdze Rodzaju opisującej wyprawę wojenną królów mezopotamskich (por. Rdz 14). We współczesnym świecie zaś obserwujemy formę imperializmu gospodarczego (wręcz neokolonializmu) nazwaną land grabbing (,grabież ziemi”). Oznacza ono zawłaszczanie ziemi rolniczej krajach ubogich (wobec wzrastającego popytu na żywność i paliwa) i przejmowanie nad nią kontroli w na potrzeby krajów bogatszych i korporacji międzynarodowych Przedmiotem transakcji są zazwyczaj duże obszary ziemi rolniczej (1-500 tys. ha), zwłaszcza w krajach afrykańskich, w Ameryce Południowej, na Ukrainie i w Kazachstanie. ${ }^{37}$ Najczęściej transakcje te zawierane są z pogwałceniem lub pominię-

35 M. S k o u s e n, Narodziny współczesnej ekonomii. Żywoty i idee wielkich myślicieli, tłum. J. S t r z e l e c k i, Warszawa 2012, s. 127.

36 Jak pokazują dalsze wersety Księgi Rodzaju (por. Rdz 19, 4-29), Lot, kierując się w swym wyborze urodzajnością okolicy, dokonał niepomyślnego wyboru. Przeciwnie Abraham, za swoją bezinteresowność i umiłowanie spokoju otrzymał nagrodę, gdyż znów ukazał mu się Bóg przyrzekający, że jego potomstwo otrzyma na wieki w posiadanie całą ziemię Kanaan; por. S. Ł a c h, Księga Rodzaju, wstęp, przekład $z$ oryginatu, komentarz, s. 336-337.

37 Por. A. Łu k a s z e w i c z, Grabież ziem uprawnych (land grabbing) jako nowa forma imperializmu ekonomicznego, Wieś i Rolnictwo 157(2012)4, s. 36-52. 
ciem prawa. Brak regulacji prawnych oraz niedostateczna kontrola tego procesu ze strony instytucji międzynarodowych prowadzi nawet do odbierania praw własności do ziem lokalnym producentom i pozbawiania ich prawa do dysponowania płodami rolnymi. Jak pięknie napisał J. Wilkin: „Dramat współczesnego gospodarowania ziemią polega na tym, że znaczna część właścicieli ziemi nigdy nie stanie fizycznie na tej ziemi ${ }^{38}$ nie pozna jej uroku, zapachu i dziedzictwa. Ta ziemia nigdy nie będzie dla nich święta [por. słowa Boga skierowane do Mojżesza: „Mojżeszu, Mojżeszu, (...) zdejm sandały z nóg, gdyż miejsce, na którym stoisz jest ziemią świętą" (Wj 3, 4-5) - M.B.]; ona będzie czynnikiem produkcji, kapitałem i źródłem zysku. To jest powód do poważnej zadumy i niepokoju". ${ }^{39}$

Zagrożenie związane z utowarowieniem przyrody, a więc poddaniem prawom wolnego rynku jej elementów, w tym ziemi, widział już przed laty ekonomista Karl Polanyi, przeciwnik liberalizmu gospodarczego, który w swym opus magnum ${ }^{40}$ opowiedział się przeciw samoregulującemu się rynkowi. Uważał, że ziemia, podobnie, jak praca i pieniądz, jest towarem fikcyjnym, gdyż, jako naturalny element przyrody, nie została wytworzona w celu sprzedawania na rynku. Cena ziemi zatem, jako „nieprawdziwego” towaru, nie powinna być określana wyłącznie przez rynek. Ta koncepcja jest bliska biblijnemu rozumieniu świętości ziemi.

\section{Odpoczynek dla ziemi}

Z obserwacji przyrody i swego doświadczenia człowiek wywnioskowat, że istnieje w przyrodzie naturalna kolejność występowania po sobie pewnych gatunków roślin, co nazywamy sukcesjami. Tak dzieje

38 Międzynarodowe korporacje i rządy, które w ramach land grabbingu zawłaszczyły olbrzymie połacie ziemi w krajach biednych, umiejscowione są niekiedy tysiące kilometrów (!) od ziemi, którą zawłaszczyli.

39 J. W i 1 k i n, Ziemia rolnicza - wielki skarb naszej planety, s. 26.

40 Por. K. P o l a n y i, Wielka transformacja. Polityczne i ekonomiczne źródła naszych czasów, tłum. M. Z a w a d z k a, Warszawa 2010. 
się zarówno w przypadku dzikiej roślinności, jak i roślin uprawnych. Mianowicie, rośliny tego samego gatunku nie znajdują najlepszych warunków rozwoju po sobie, lecz odwrotnie, wiele innych roślin jest lepszym dla nich przedplonem (czyli rośliną poprzedzającą). $Z$ faktem obniżenia się plonów i zjawiskiem ,zmęczenia gleby” przy powtórnych zasiewach tej samej rośliny człowiek spotkał się dość wcześnie. W zaraniu rolnictwa karczował on lasy i obsiewał karczunek przez wiele lat zazwyczaj tą samą rośliną. $Z$ powodu wyjałowienia ziemi, plony przy takiej gospodarce spadały z roku na rok, tak że musiał zarzucać uprawę tego pola i karczować nowe tereny. Dotychczas użytkowane pole leżało odłogiem i dopiero po wielu latach powracano do jego uprawy. Od dawna już zauważono, że wszędzie tam, gdzie nie zmienia się co rok jednej rośliny na inną, nawet jednoroczne zaniechanie uprawy powoduje polepszenie warunków. W ten sposób krystalizował się system odłogowy w gospodarce rolnej.

W odłogowym systemie użytkowania ziemi pole obsiewano przez kilka lat, a gdy urodzajność jego spadała, pozostawiano je nieuprawiane na lat kilkanaście. Gdy ziemia „odpoczęła”, brano ją znów pod uprawę. Podczas odłogowania następowała odbudowa żyzności i urodzajności gleby, która sprzyjała urodzajowi plonów. Wraz z rozwojem gospodarki rolnej, a także przyrostem ludności, wprowadzono system ugorowy. W tym zaś systemie okres odbudowy struktury i nawrotu żyzności gleby zmalał do jednego roku. W tym czasie na pole „rzucały” się gwałtownie chwasty (bo takie jest prawo sukcesji), dlatego rolnik zmuszony był niszczyć je, stosując przez cały okres wegetacyjny uprawę mechaniczną roli (jej „wzruszanie”). Tak oto tłumaczą istotę i sens systemu ugorowego i odłogowego ${ }^{41}$ współczesne księgi agronomii i uprawy roślin. ${ }^{42}$

Jednak ową mądrość „odpoczynku ziemi” odnajdujemy już w księgach sprzed kilku tysięcy lat. Nasze tropy kierujemy do Księgi

41 Rozróżnienie między odłogami a ugorami istnieje do dziś: ugór podlega choć raz w roku zabiegom uprawnym, zaś odłóg nie podlega żadnym zabiegom pielęgnacyjnym.

42 Por. B. Ś w i ę t o c h ow s k i, Ogólna uprawa roślin, Warszawa 1959, s. 591$-592 ; 617-619$. 
Wyjścia oraz do Księgi Kapłańskiej, gdzie mowa jest o szabacie dla ziemi. Czytamy w Księdze Wyjścia o nakazie Pańskim: „Przez sześć lat będziesz obsiewał ziemię i zbierał jej płody, a siódmego pozwolisz jej leżeć odłogiem (...) tak też postąpisz z twoją winnicą i z twym ogrodem oliwnym" (Wj 23, 10-13). Siódmy rok (w księgach świętych nie podaje się, czy ta data miała charakter powszechny i stały, czy też była ruchoma $\mathrm{w}$ zależności od momentu, w którym rozpoczęto uprawę) miał być rokiem odpoczynku, a więc rokiem szabatowym. Choć, jak się wydaje, główną przesłanką roku szabatowego była racja religijna (Jahwe jest właścicielem ziemi, do Niego należą płody ziemi i On rezerwuje sobie płody siódmego roku $^{43}$ ), nie można wykluczyć Mądrości Bożej stwarzającej ziemię, jej cykle, rozwój jej żyzności, mądrości, która przewidziała „racje gospodarcze” zapobiegające wyjałowieniu ziemi i zwiększenia jej żyzności przez odpoczynek. ${ }^{44}$

Zawsze jednak szabat miał być dla Boga. Sam Pan powiedział Mojżeszowi: „Kiedy wejdziecie do ziemi, którą daje wam, wtedy ziemia będzie także obchodzić szabat dla Pana (...) w siódmym roku będzie uroczysty szabat dla ziemi, szabat dla Pana” (Kpł 25, 2.4). Szabat ma być uświęceniem i uczczeniem suwerennej władzy Boga-Jahwe i świadczyć o przynależności do Niego. W Katolickim komentarzu biblijnym znajdujemy wyjaśnienie, że zwyczaj okresowego nieobsiewania ziemi, nota bene w celu zapewnienia przyszłego urodzaju, znany był w społecznościach starożytnego Bliskiego Wschodu, ale u Izraelitów nabrał nowego znaczenia skoncentrowanego na wyłącznej własności Jahwe wyrażającej się w koncepcji roku szabatowego. ${ }^{45}$

43 Por. S. Ła c h, Księga Wyjścia. Wstęp, przekład z oryginatu, komentarz, w: te n ż e (red.), Pismo Święte Starego Testamentu, t. 1, cz. 2, s. 227.

${ }^{44}$ W Słowniku teologii biblijnej czytamy wprost: „Żeby nie w y j ało w i ć [podkreślenie - M.B.] ziemi za bardzo, co siedem lat należy zrezygnować ze zbioru plonów (Wj, 23, 11)"; X. L e o n - D u fo u r (red.), Słownik teologii biblijnej, tłum. K. R o m a n i u k, Poznań 1990, s. 1131.

45 Por. R. E. Brown, J. A. Fitzmyer, R. E. Murphy (red. wydania oryginalnego); W. Ch rost ow s k i (red. nauk. wyd. pol.), Katolicki komentarz biblijny, s. 125. 
Bóg udzielił błogosławieństwa na rok szabatowy, zapewniając obfity plon w szóstym roku uprawy, tak że plony miały wystarczyć na trzy lata, rok poprzedzający, rok szabatu, a nawet na pierwszy rok poszabatowy (por. Kpł 25, 20-22). Tak więc zachowanie roku szabatowego, zostawienie ziemi odłogiem na jeden rok, nie powodowało żadnych niepożądanych gospodarczo efektów. Bóg - Kreator świata i najlepszy jego zarządca, zapewnił o obfitości, ale pod warunkiem przestrzegania Jego przykazań. „Jeżeli będziecie postępować według moich ustaw (...), dam wam deszcz w swoim czasie, ziemia będzie przynosić plony (...), będziecie jedli chleb do sytości, będziecie mieszkać bezpiecznie w swoim kraju (Kpł 26, 3).

Rok odpoczynku dla ziemi wyrażał troskę Boga nie tylko w stosunku do uprawiających ziemię, ale też do ubogich, bowiem postanowił Pan: „Nie dokonasz zbioru [w siódmym roku - M.B.], aby mogli jeść ubodzy z twego ludu, a resztę zjedzą dzikie zwierzęta. Tak też postąpisz z twoją winnicą i twoim ogrodem oliwnym" (Wj 23, 11). Chodziło o pozostawienie tego, co ziemia samoistnie wyprodukowała, tj. zboża wyrosłego bez siana i ziarna pozostałego z ostatnich żniw, jak i winogron nieobcinanych, których kiście wyrosły same. ${ }^{46}$ Przepisy te tworzą ramy starotestamentowej ,polityki społecznej”. Bóg, prawdziwy właściciel ziemi, dysponuje jej produktami na korzyść wszystkich mieszkańców ziemi. ${ }^{47}$ Następujący co siedem lat szabat ziemi związany był z szabatem pracy (następującym co siedem dni): „Sześć dni będziesz pracował, a dnia siódmego zaprzestaniesz pracy, aby odpoczęły twój wół i osioł i odetchnęli syn twojej niewolnicy i cudzoziemiec" (Wj 2, 10). Tak zatem jak i ziemia, tak i cała społeczność powinna mieć szabat.

46 Por. S. Ł a c h, Księga Kapłańska. Wstęp, przekład z oryginatu, komentarz, ekskursy, s. 270.

47 Przykładem troski Boga o każdego człowieka są także przepisy dotyczące dziesięcin trzyletnich dla ubogich i cudzoziemców (por. Pwt 14, 28-29; Pwt 26, 12-13) oraz pozostawiania dla nich kłosów, oliwek i winogron (prawo do pokłosia; por. Kpł 19, 9; Kpł 23, 22; Pwt 24, 19-22). 
Przestrzeganie szabatu wiązało się ze szczególnym znaczeniem Ziemi Obiecanej. Jako dar Boga, stawała się ona świętym terytorium, na którym miało obowiązywać Prawo określone przez Jego świętą wolę. Ziemia stawała się w ten sposób przestrzenią, którą wypełniają zobowiązania przymierza.

Praktyka rolna okresowego odpoczynku ziemi, rok odłogu, roku wytchnienia dla ziemi, do dziś przetrwała w Syrii i Palestynie. W Europie natomiast ugór stanowił powszechny element użytkowania ziemi (od początków istnienia rolnictwa) aż do połowy XIX w., kiedy to zaczęto stosować system płodozmianowy (tzw. zmianowanie norfolskie). W miarę postępu technicznego, biologicznego oraz zmian organizacyjno-ekonomicznych w rolnictwie, w II połowie XX w. ugorowanie zaczęło jeszcze bardziej tracić na znaczeniu, głównie ze względu na wzrastające możliwości stosunkowo łatwego uzupełniania składników pokarmowych w glebie przez nawożenie mineralne oraz regulację zachwaszczenia za pomocą herbicydów. ${ }^{48}$ Okazało się jednak, że naturalnych praw przyrody nie da się „,przechytrzyć”; w czasach współczesnych ugorowanie odradza się w ramach tzw. ekologizacji rolnictwa. Za przykład próby ,powrotu do natury” może posłużyć polityka Unii Europejskiej wyrażona w tzw. greeningu, czyli zazielenianiu, m. in. przyznawaniu dopłat bezpośrednich dla rolników, pod warunkiem utrzymania pewnego odsetka obszarów proekologicznych, za które uznano również grunty ugorowane. ${ }^{49}$

\section{Cykliczna urodzajność ziemi}

W Piśmie Świętym, bodaj po raz pierwszy w całej pisanej historii, mowa jest o cyklu gospodarczym. Cykl koniunkturalny (gospodarczy) to fluktuacja aktywności gospodarczej. Za Markiem Skousenem, cykl koniunkturalny definiujemy jako „wzloty i upadki

48 Por. J. N ow i ck i, M. M a rk s, P. M a k ow s k i, Ugór jako element współczesnego krajobrazu rolniczego, Fragmenta Agronomika 96(2007) 4, s. 49.

49 Por. J. D a l e s z y ń s k i, Greening. Tak zrobisz to najlepiej, Poznań 2015, s. 4-9. 
gospodarki określone za pomocą PKB, poziomu zatrudnienia i zysków przedsiębiorstw". ${ }^{50}$ Są to w gruncie rzeczy powtarzające się prawidłowości rozwoju gospodarczego. W cyklu gospodarczym występują dwie ogólne fazy: ekspansji i kontrakcji, czyli spadku, lub szczegółowe fazy rozwoju: rozkwit, recesja, depresja i ożywienie. W różnych teoriach różnie szacowane są długości czasowe między dwoma okresami szczytowego wzrostu lub depresji, np. cykl Kuznetsa: od 15 do 18 lat, cykl Kondratiewa: od 45 do 60 lat. ${ }^{51}$ Zazwyczaj wskaźniki ekonomiczne cyklu poruszają się w tym samym kierunku (wzrostu lub spadku).

Co sprawia, że rynki przeżywają fazę wzrostów i załamań w pozornie niekończącym się cyklu? Czy cykl można kontrolować lub zminimalizować jego negatywny wpływ? W ekonomii zaproponowano wiele teorii cyklu koniunkturalnego. O wzloty i upadki „obwiniano" różne zjawiska, począwszy od plam na słońcu, a skończywszy na polityce monetarnej (zmian w podaży pieniądza i wysokości stóp procentowych). W nauce nie ma zgodności co do przyczyn cyklicznego rozwoju gospodarczego, wskazuje się zarówno na przyczyny endogeniczne: cykle są związane z wewnętrzną strukturą i zmianami systemu gospodarczego; wynikające z rozwoju gospodarczego, lub przyczyny egzogeniczne: zjawiska destrukcyjne poza systemem (np. wojny). I mimo przyznania, w dziedzinie ekonomii, Nagrody Banku Szwecji im. Alfreda Nobla Friedrichowi von Hayekowi (1974 r.) za analizy cyklów koniunkturalnych, sprawa cykli nie została do końca poznana i rozwiązana na tyle, by można było tak sterować gospodarką, by ich uniknąć. Ostatni kryzys 2008 r. pobudził znów debatę nad przyczynami kryzysu i sposobami wyjścia z niego. Tyle w ogólnym zarysie mówi nauka, próbująca odnaleźć (ale wciąż nie odnajdująca) jednoznaczne przyczyny recesji i cykli gospodarczych.

W Biblii znajduje się opis pierwszego cyklu koniunkturalnego w historii ludzkości. Owiany jest on pewną tajemnicą. To sen faraona

50 M. S k o u s e n, Narodziny współczesnej ekonomii. Żywoty i idee wielkich myślicieli, s. 659.

51 Por. J. S z p a k, Historia gospodarcza powszechna, Warszawa 2007, s. 49. 
o siedmiu tłustych i siedmiu chudych krowach oraz o siedmiu pełnych kłosach i siedmiu pustych (por. Rdz 41, 1-4). Z Nilu, stanowiącego źródło urodzajności, jak i nieurodzajności ziemi, wyszło według snu faraona najpierw siedem krów pięknych i tłustych, następnie zaś siedem krów brzydkich i chudych. Finał był przerażający, gdyż oto siedem krów chudych pożarło siedem tłustych. Komplementarną i paralelną częścią snu faraona było widzenie siedmiu kłosów zdrowych i pięknych oraz siedmiu pustych, które wchłonęły owe zdrowe kłosy. Józef, syn Jakuba, którego faraon poprosił o wytłumaczenie snu, ${ }^{52}$ tak oto zinterpretował ów sen: po siedmiu latach obfitości nastąpi siedem lat głodu (por. Rdz 41, 25-30), podkreślając, że jest to zapowiedź Boga dotycząca tego, co On zamierza uczynić. Można to tłumaczenie Józefowe uznać za swego rodzaju makroekonomiczną prognozę. Józef okazał się zdolnym przedsiębiorcą i zarządcą, dziś powiedzielibyśmy, managerem, gdyż udzielił faraonowi, jak się okazało, skutecznej rady, w jaki sposób działać w zbliżającej się sytuacji nastania głodu. Możemy powiedzieć, że Józef zajął się tym, nad czym głowi się dziś Organizacja Narodów Zjednoczonych ds. Wyżywienia i Rolnictwa (FAO), nad odwiecznym problemem głodu. ${ }^{53}$ Otóż Józef rzekł tak: „Niech faraon tak ustanowi nadzorców, by zebrać piątą

52 Dlaczego faraon był przejęty widzeniem sennym? Odpowiedź znajdujemy w egzegezie biblijnej. Otóż, faraon, jak i zwyczajni Egipcjanie, przywiązywał wielką wagę do snów. Wiara w sny opierała się u nich na przekonaniu, że sen kontaktuje ludzi z zaświatem, gdzie mieszkają zmarli i bogowie. Od snów zależały najważniejsze państwowe postanowienia. Waga tego snu była wzmocniona znaczącymi symbolami. Mianowicie, rzeką Nil, uważaną za bóstwo przez starożytnych Egipcjan (od jej wylewów zależały zbiory w Egipcie) oraz symbolem siedmiu krów występującym w mitologii egipskiej (Ozyrys ukazywany był często w otoczeniu siedmiu krów, które zaopatrywały go w żywność po śmierci); por. S. Ł a c h, Księga Rodzaju. Wstęp, przekład z oryginału, komentarz, s. 490-491.

${ }_{53} \mathrm{Z}$ raportu FAO wynika, że z powodu niedożywienia cierpi na całym świecie 794,6 mln ludzi, co stanowi 10,9\%. W niektórych krajach głoduje prawie połowa ludności, np. Haiti - 53,4\%, Zambia - 47,8\%, Republika Środkowej Afryki - 47,7\%. Są też kraje, które pod względem procentowym nie znajdują się w niechlubnej czołówce, ale pod względem liczby głodujących mieszkańców zdecydowanie przodują, m.in. Chiny - 133,8 mln osób; zob. F A O, I F A D, W F P, The State of 
część urodzajów w Egipcie podczas siedmiu lat obfitości. Niechaj oni nagromadzą wszelką żywność podczas tych lat pomyślności, które nadejdą. (...) A będzie ta żywność zachowana dla kraju na siedem lat głodu, które nastaną w Egipcie. Tak więc nie wyginie ludność tego kraju z głodu" (Rdz 41, 34-36).

Tomáš Sedláček w swej znakomitej książce Ekonomia dobra $i$ zła zauważa, że to jest pierwsza wzmianka w Piśmie Świętym o wprowadzeniu podatków (w wysokości jednej piątej plonów) w latach prosperity, aby oszczędzić zboże i zachować go na lata złe. ${ }^{54} \mathrm{Za}-$ uważa też, że tym sposobem nie doszło do spełnienia się złowrogiej przepowiedni. Albowiem, jeżeli umiemy przewidzieć problemy i podejmujemy odpowiednie przeciwdziałanie, $\mathrm{z}$ reguły nie dochodzi do ich powstania. W Egipcie nie zapanował głód dzięki zastosowaniu intuicyjnej, aczkolwiek rozsądnej ,polityki gospodarczej” Józefa.

Wspomniany fragment przywodzi na myśl także oszczędzanie, jedną z kwestii ekonomicznych. Jak widzimy, „od wieków” cnota oszczędzania leżała $\mathrm{w}$ najlepszym interesie jednostki czy też narodu. Tak tę kwestię widzieli również klasyczni ekonomiści, jak np. ojciec ekonomii, Adam Smith. ${ }^{55}$ Za przyczyną poglądów wpływowego ekonomisty, Johna Keynsa i kontynuatorów jego myśli, myślenie takie zostało wywrócone do góry nogami. Keynsiści bowiem krytykują powiększanie oszczędności kosztem konsumpcji, twierdząc, że ,jeżeli naród jako całość postanowi oszczędzać, wynikiem może być powszechna recesja i ubóstwo". ${ }^{56} \mathrm{Nie}$ ma tu miejsca na wchodzenie w spory ekonomiczne, dodam jednak, że pojawili się obrońcy „ataku na oszczędzanie”, m. in. ekonomiści szkoły austriackiej,

Food Insecurity in the World, Meeting the 2015 international hunger targets: taking stocks of uneven progress, Rome, 2015, s. 8, 44-47.

${ }^{54}$ Por. T. S e d lá č e k, Ekonomia dobra $i$ zła. W poszukiwaniu istoty ekonomii od Gilgamesza do Wall Street, tłum. D. B a k a 1 a r z, Warszawa 2012, s. 76.

55 W ekonomii, nota bene, jak w Piśmie Świętym, „wszystko zaczęło się od Adama" (to tytuł pierwszego rozdziału książki M. S k o u s e n a, Narodziny współczesnej ekonomii). Adam Smith dał początek nauce zwanej ekonomią swym dziełem Badania nad natura i przyczynami bogactwa narodów (1776).

56 M. S k o u s e n, Logika ekonomii, s. 425. 
którzy dowodzą, że błędem jest stwierdzenie, jakoby oszczędzanie było przyczyną kryzysu, przeciwnie, jest ono jego skutkiem. ${ }^{57} \mathrm{~W}$ ten sposób historia zatoczyła koło, wracając do stylu polityki fiskalnej przedstawionej w Piśmie Świętym.

Ze snu faraona spełniła się wizja prognozy makroekonomicznej, zapowiadającej lata urodzajności i lata nieurodzaju, innymi słowy, zapowiadającej zbliżający się cykl koniunkturalny w gospodarce, ale dzięki mądrości Józefa, nie spełniło się widmo głodu w Egipcie. Kiedy zatem nastał czas nieurodzaju, a w Egipcie głód zaczął dawać się we znaki, ludność domagała się chleba od faraona. Wtedy faraon, jak mówi Księga Rodzaju, powiedział do Egipcjan: „Udajcie się do Józefa i co on wam powie, czyńcie" (Rdz 41, 55).

Zwróćmy uwagę na przedsiębiorczość Józefa, na jego rządy w Egipcie. Najpierw sprzedawał zboże za pieniądze, gdy zaś te wyczerpały się Egipcjanom i mieszkańcom Kanaanu, wtedy dokonywał wymiany barterowej: zboże za żywy dobytek, gdy po roku zaś i te się wyczerpały, sami głodujący zaproponowali Józefowi: „Kup więc nas i ziemię naszą za chleb; będziemy niewolnikami faraona, a nasza ziemia będzie [jego własnością]. Byleś dał nam ziarno do siewu, a przetrwamy, nie pomrzemy i nasza ziemia nie będzie leżeć odłogiem" (Rdz 47, 19). Widzimy tu także, jak nieocenioną wartość ma ziemia-matka żywicielka dla każdego pokolenia, od biblijnego do współczesnego. Józef zrobił tak, jak mu zaproponowano: wykupił wszystkie grunty w Egipcie (tu potwierdza się ważność prawnego uregulowania własności ziemi), z wyjątkiem gruntów kapłanów, w ten sposób ziemia stała się własnością faraona. Ludowi zaś dał Józef ziarno do obsiania ziemi. Nakazał, by po żniwach oddawać piątą część plonów faraonowi, resztę zachowując na potrzeby własne. Zachował zatem Józef prawo ,podatkowe” wprowadzone w latach obfitości.

Józef przeprowadził z sukcesem przejście przez meandry cyklu gospodarczego. W Księdze Rodzaju, opisującej ów cykl, nie znajdujemy

57 Por. H. H a z lit t, Ekonomia w jednej lekcji, tłum. G. Ł u c z k i e w i c z, Warszawa 2012, s. 162. 
bezpośredniego wytłumaczenia przyczyn zmieniającej się koniunktury. Myślę, że jest to spowodowane przyjmowaniem wszystkich wydarzeń dziejących się w historii narodu wybranego z ufnością w zamysł Bożej Mądrości. Po prostu, Bóg jako Stwórca ziemi, daje lata tłuste i daje lata chude, daje urodzajność bądź nieurodzajność ziemi, czyni tak, jak chce, i ma prawo tak czynić, bo jest Bogiem. Jednak możemy się dopatrzeć pewnego wyjaśnienia nie tyle tego, dlaczego tak się dzieje, ale tego, co czynić, by tak się nie działo. Otóż, możemy stwierdzić, że przyczyny cykliczności koniunktury mają charakter moralny ${ }^{58}$ Mianowicie, gdy przestrzegano przykazań i praw Pana, naród doskonale prosperował, w sytuacjach odwrotnych - dochodziło do kryzysów. O warunku tym mówi sam Bóg w wielu miejscach Pięcioksięgu, np. passusy z Księgi Powtórzonego Prawa, dla przykładu następujący fragment: „Jeśli będziecie słuchać pilnie nakazów, które wam dziś daję, miłując Pana, Boga waszego, i służąc Mu z całego serca i z całej duszy, ześle On deszcz na waszą ziemię we właściwym czasie, jesienny, jak i wiosenny, i zbierzecie wasze zboże, moszcz i oliwę. Da też trawę na polach dla waszego bydła. Będziecie mieli żywności do syta" (Pwt 11, 13-14).

Dla narodu wybranego przestrzeganie praw Bożych, a więc życie moralne, miało być najlepszą inwestycją, zapewniającą materialny dobrobyt na ziemi. Echa tej pradawnej mądrości pobrzmiewają coraz głośniej we współczesnej myśli ekonomicznej, zwłaszcza po światowym kryzysie gospodarczym z 2008 r. Weźmy dwa przykłady. Pierwszy, to książka Przewodnik po moralnym kapitalizmie, ${ }^{59}$ która pokazuje, że nie jest to bynajmniej przewodnik po Nibylandii. Drugi, to Kryzys ekonomiczny a kryzys wartości, w której autorzy, Paul H. Dembinski i S. Beretta, stawiają tezę, że wyjście z kryzysu jest możliwe przez przeniknięcie porządku społecznego moralnością. „Prawdziwym wyzwaniem na przyszłość jest odbudowa sił

58 Por. T. S e d láč e k, Ekonomia dobra i zła, s. 78.

59 T. D ołęg o w s k i, Przewodnik po moralnym kapitalizmie, Warszawa 2015. 
kapitalizmu od zewnątrz (poprzez regulacje) i od środka (poprzez cnotliwe zachowania)". ${ }^{60}$ Zaiste.

$$
* * *
$$

Tak oto zakończyłam moją przygodę naukową, nota bene $\mathrm{z}$,posmakiem duchowym", w głąb Pięcioksięgu w poszukiwaniu ,szkiełkiem i okiem" źródeł współczesnego spojrzenia ekonomicznego na kategorię ziemi, a tym samym wzajemnych powiązań (i wynikań) między ekonomią a teologią. Okazało się, że trop był właściwy, bowiem w Biblii znajduje się niemało odniesień, często szczegółowych, dotyczących ziemi, zarówno jej wartości, własności, jak i „filozofii” uprawy i urodzajności. Można je uznać za archetypy, gdyż one były pierwsze przed prawami, które na temat ziemi wykłada nam ekonomia, która wszak jest nauką młodą, ,jedynie” ponad 200-letnią. Mało tego, odnajdujemy nie tylko podobieństwo co do faktu istnienia samego zjawiska, ale i co do kierunku jego rozwoju: to, co znajdujemy w Piśmie Świętym, echem sprzed tysięcy lat odbija się w ekonomii i dziś. Przykładem niech będzie przywoływane zjawisko tzw. tragedii wspólnego pastwiska, związane z nadmiernym używaniem ograniczonych zasobów ziemi w sytuacji własności publicznej, a w Piśmie Świętym archetypizowane opowieścią o rozdzieleniu stad trzód Lota i Abrama, która pokazuje nam nie tylko diagnozę problemu, ale i sposób jego rozwiązania (por. Rdz 13, 6).

Odszukiwanie i znajdowanie w Pięcioksięgu archetypów dotyczących ziemi, nie oznacza bynajmniej, wieloznaczności języka Biblii, nie daje też prawa do swobodnej interpretacji. Odsłania raczej wieloznaczeniowość Pisma Świętego. Jak tłumaczy Waldemar Chrostowski, „tekst święty bywa wieloznaczeniowy, to znaczy nie wyczerpuje swego sensu w tylko jedynym sposobie rozumienia i objaśniania". ${ }^{61}$

${ }^{60}$ P. H. D e m b i n s k i, S. B e r e t t a, Kryzys ekonomiczny i kryzys wartości, tłum. Ł. K o m u d a, Kraków 2014, s. 143.

${ }^{61}$ Bóg, Biblia, Mesjasz. Z księdzem profesorem Waldemarem Chrostowskim rozmawiają: Grzegorz Górny i Rafat Tichy, Warszawa 2007, s. 429. 
Moje zadanie badawcze, polegające na zabiegu odnoszenia wiedzy współczesnej ekonomii do wiedzy biblijnej i konfrontowania go, polegało właśnie na odnajdywaniu „wieloznaczeniowości”, tzn. innego, bo ekonomicznego sposobu rozumienia sensu słowa Bożego.

Byłoby nadużyciem stwierdzenie, że współczesna ekonomia wzięła początek, a nawet, że zaczerpnęła z Pisma Świętego, ale jest prawdą to, że „dziwnym zbiegiem okoliczności” wiele kierunków myśli ekonomicznej zbieżne jest z prawami zawartymi w Pięcioksięgu, co świadczy o uniwersalności i ponadczasowości Biblii. Parafrazując przywołany przez Michała Hellera cytat z Alfreda N. Whiteheada, że cała historia filozofii sprowadza się do kilku przypisów do Platona, ${ }^{62}$ można pokusić się o tezę mówiącą, iż myśl ekonomii współczesnej często stanowi przypisy do Biblii rozwijające myśl zawartą w świętych tekstach.

Marta BEADD

Słowa kluczowe: Pięcioksiąg, ekonomia, ziemia, gleba

Keywords: Pentateuch, Economics, Land, Soil

\section{Between Economics and Theology: Economical Archetypes of the Land in the Pentateuch}

Summary

An interdisciplinarity becames more and more popular approach in contemporary science to explaning the complexity of the world. The article tries to show that the Bible is a genuine source where we can find many archetypes of various economical theories and concepts. One of them is land, soil itself. From the economical point of view land is one of the primary factors of production. Land has got not only economical value, but also social and cultural. The Bible is a great source of inspiration for many economical ideas concerning land, i.e. the value of land, ownership of land

${ }^{62}$ Por. M. He 11 e r, Bóg i geometria, Kraków 2016, s. 5. 
and cyclical fertility of the soil (vide: Sabbath rest). The main goal of this paper is to find and compare the contemporary economical knowledge to the knowledge of the Pentateuch and provide an economic explanation for the word of God. 